\title{
Design Approach for the Optimal Model of an Energy-Efficient Timber Building with Enlarged Glazing Surface on the South Façade
}

\author{
Vesna Žegarac Leskovar ${ }^{1}$ and Miroslav Premrov*2 \\ ${ }^{1}$ Dr. Lecturer, Faculty of Civil Engineering, University of Maribor, Slovenia \\ ${ }^{2}$ Professor, Faculty of Civil Engineering, University of Maribor, Slovenia
}

\begin{abstract}
This paper presents the reasonability of using an increased proportion of glazing surfaces in prefabricated timber-frame buildings with a special focus on energy efficiency by using an enlarged glazing area in the south façade. The research is based on a case study of a two-storey house built in a prefabricated timberframe structural system taking the climate data for Ljubljana into consideration. Parametric analysis is performed on the variation of an increased proportion of the glazing surface's impact in the south side of the building according to the total surface of the south façade (AGAW) as a basic variable. The analysis was carried out on different exterior wall elements having different thermal properties, while the rest of the parameters, such as the ground plan of the model as well as the active systems, roof and floor slab assemblies, climate condition, etc. remain constant. The basic theoretical contribution of the presented research is the transformation of a complex energy related problem to only one single independent variable $\left(\mathrm{U}_{\text {wall }}{ }^{-v a l u e}\right)$ which becomes the only variable parameter to determine the optimal glazing area size value $\left(A G A W_{\text {opt }}\right)$ for all contemporary prefabricated timber construction systems.
\end{abstract}

Keywords: timber; energy efficiency; glazing; modeling

\section{Introduction}

The present times, characterized by specific circumstances in the sphere of climate change, witness an intensive focus of the sciences of civil engineering and architecture in searching for ecological solutions and construction methods that would allow for greater energy efficiency and, consequently, for a reduced environmental burden. The brick and concrete industry is responsible for about $10 \%$ of global $\mathrm{CO}_{2}$ emissions into the environment whereas wood helps the environment by absorbing and storing $\mathrm{CO}_{2}$ while it grows. Being a natural raw material, timber represents one of the best choices for energy efficient construction since it also functions as a material with good thermal properties if compared to other construction materials, has good mechanical properties and ensures a comfortable indoor living climate. Respecting all these facts the energy-efficient properties of timberframe buildings are, in comparison with other types of building, constructed with concrete, brick or steel, excellent but not only because well-insulated buildings use less energy for heating, which is environmentally

* Contact Author: Miroslav Premrov, Faculty of Civil Engineering, University of Maribor, Smetanova ul. 17, SI-2000 Maribor, Slovenia

Tel: +386-2-2294300 Fax: +386-2-2524179

E-mail: miroslav.premrov@uni-mb.si

(Received April 12, 2011 ; accepted January 23, 2012) friendly, but also due to the extremely positive feelings that homeowners have when living in such houses.

Additionally the use of glazing surfaces in timber structures is becoming an important issue of energyefficient construction. Over a number of years of development, glazing manufacturers have improved their products' thermal-insulation and strength properties as well as their coefficient of permeability of total solar radiation energy and thus enabled the use of large glazing surfaces, primarily south-oriented, not only to illuminate indoor areas but also to ensure solar heating. It follows that timber construction along with the use of suitable and correctly oriented glazing surfaces represents a great potential in residential and public building construction. Many studies have been performed since then focusing on the research of specific parameters that influence the energy performance of buildings.

The research of general methods for estimating the total area of the exposed surface of domestic buildings by authors Steadman and Brown (1987) was performed on the basis of an empirical study of a house plan from the city of Cambridge. Among a range of researched parameters, such as the relationship between the wall area and floor area, built form etc., the glazing areas are examined from the viewpoint of heat loss. Interest is focused principally on south-oriented glazing. Among comparable latter studies a parametric study of heating and cooling demand was performed by Bülow-Hübe (2001) in order to determine the optimal 
design for office windows for the Swedish climate. The study is based on a single-person office model with windows in the south facade. It includes many variable parameters, such as glazing size, type and orientation, daylight utilisation, internal load, ventilation rate, wall insulation and climate. Another Swedish study was performed by Persson et al (2006a) for 20 low-energy terraced houses built in 2001 outside Gothenburg. The analysed houses are oriented with the large window area facing south and the building construction is more air tight and more insulated than traditional houses in Sweden. The variable parameters of this research are the orientation, U-values of the construction elements and different triple glazed window combinations. It is shown that less energy is needed for heating if the houses are placed with the large window area facing south. Orienting the windows to the west or east does not noticeably influence the energy balance. Next, many findings are stated in the dissertation of Persson (2006b) which are in some respects comparable to the authors' research. According to Pagliano et al. (2007) the optimum glazing surface for mild winters is equal to $30 \%$ of the total surface of the building. In locations with more severe winters this optimum does not exist but a glazing surface of between $15 \%$ and $30 \%$ of the total surface is recommended.

Among the existing studies many of them are provided for non-European climates. Bouden (2007) investigated whether glass curtain walls are appropriate for the Tunisian climate. The influence of windows on the energy balance of apartment buildings in Amman, Jordan, is analysed in a study performed by Hassouneh et al. (2010). In general all of the presented studies deal mainly with the influence of variable parameters on the energy performance of buildings of different types (residential, offices, public) and mainly of massive construction systems. From the existing research the authors can summarize that the process of defining the optimal residential building is very complex, and is influenced by the specific basic parameters listed below:

- location of the building and climate data for the specific location,

- orientation of the building,

- properties of installed materials, such as timber, glass, insulation, boards etc.,

- building design (form, ground plan, composition of the building envelope, window size and arrangement in the façade),

- selection of active systems.

One of the general critical remarks of the authors regarding existing studies on the impact of windows on heating and cooling demand was that most of them are just calculations for a single building. In the authors' research an attempt for a more systematic analysis has been made, with the model of a building of their base-case study being performed in many variations of timber construction systems.

The first part of the paper presents the principal timber structural systems as well as the main preferences regarding low-energy construction. Some basic energy-efficient house design requirements are presented in Chapter 2. The second part, starting with Chapter 3, focuses on the reasonability of using an increased proportion of glazing surfaces performed on a parametric analysis on a two-storey timber-frame house. Based on the parametric analysis Chapter 4 presents the generalisation of the problem related to the energy demand dependence as well as the optimal glazing area size dependence on one single variable, the $U_{\text {wall }}$-value, which becomes the only variable parameter for all contemporary prefabricated timber construction systems, independently of the type of construction system. Calculations do not consider various active systems' impacts (heat recovery ventilation, solar collectors, PV panels, heat pumps, etc.). The comparative analysis results can nevertheless serve as a good frame of reference for civil engineers and architects in an approximate estimation of energy demands accompanying the different positioning and proportion of glazing surfaces while using various prefabricated timber-frame wall elements. It is important to stress that the presented analysis is limited to timber construction only, therefore a specific thermal capacity of lightweight timber structures is considered in all calculations.

\section{Energy Efficiency of Timber-Frame Buildings 2.1 Timber-frame construction system}

Timber is commonly associated with lightweight construction although it is ubiquitous as a building material. Timber construction is an important part of the infrastructure in a number of areas around the world. Brand new and improved features, having been introduced in the early 80 's of the last century, brought about the expansion of timber-frame buildings all over the world. The most important are the following introduced changes: transition from on-site construction to prefabrication in a factory; transition from elementary measures to modular building and development from a single-panel to a macro-panel wall prefabricated panel system. All of these greatly improve the speed of building. Respecting all these facts the energy-efficient properties of timber-frame buildings are, in comparison with other types of buildings (brick, concrete, steel) excellent, but not only because well insulated buildings use less energy for heating, which is environmentally friendly, but also due to the extremely positive feelings of homeowners when living in such houses. There are two main and competitive prefabricated structural systems mostly used in residential timber buildings: a timber-frame system and a massive panel system. In this research the authors' attention is focused on the timber-frame 
construction system. The behaviour of the massive panel system is very similar to the timber-frame, some comparison of the calculated results can be found in Žegarac and Premrov (2010).

Prefabricated single-panel timber-frame walls as main vertical bearing capacity elements, of usually typical dimensions with a width $\mathrm{b}=1250 \mathrm{~mm}$ and $\mathrm{a}$ height $\mathrm{h}=2500-2600 \mathrm{~mm}$, are composed of a timber frame and sheets of board-material fixed by mechanical fasteners to both sides of the timber frame (Fig.1.).

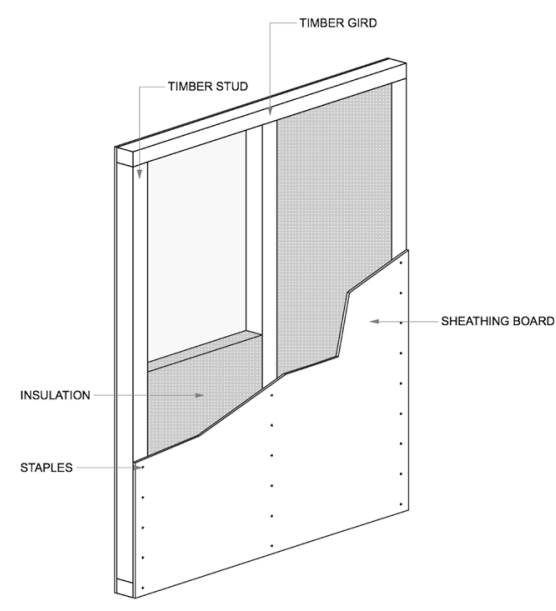

Fig.1. Composition of a Single-Panel Timber-Frame Wall Element

There are many types of panel sheet products available which may have some structural capacity such as wood-based materials (plywood, oriented strand board, hardboard, particleboard, etc.) or fibreplaster boards (FPB), originally started in Germany and recently the most frequently used type of boards in Central Europe, Premrov and Kuhta (2009). The sheathing boards on both sides of the wall can be covered with a $12.5 \mathrm{~mm}$ gypsum-cardboard. Development from an old single-panel to a new macropanel wall system (Fig.2.) in the middle of the 90's of the last century also greatly increased the speed of building.

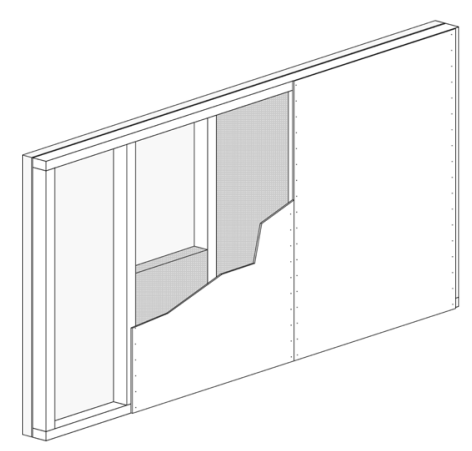

Fig.2. Composition of a Macro-Panel Timber-Frame Wall Element

Because all elements in timber-frame walls are prefabricated, the erection of such a building is very fast. The wall elements in a total length up to 12.5 $\mathrm{m}$, containing all protection and insulation layers as well as window and door openings, are completely produced in a factory, Kozem Šilih and Premrov (2010).

\subsection{Basic requirements of energy-efficient house design}

The definition of an energy efficient house design is related to the specific design approach comprising exactly defined parameters which influence the energy balance of buildings. The basic aim of energyefficient house design is to take advantage of as many renewable energy sources and of climatic conditions in combination with low energy technology as possible in order to reduce the need for conventional building technology which is inefficient or consumes a lot of fossil fuel energy. Parallel to a reduced demand for a fossil fuel to heat the building, the $\mathrm{CO}_{2}$ emissions are reduced as well.

There exist few classifications of energy-efficient houses that differ from each other minimally regarding energy demand. As an example a low-energy house is a house with an annual requirement for a space heating energy demand of less than $50 \mathrm{kWh} / \mathrm{m}^{2} \mathrm{a}$, however the requirements differ from one country to another, while for a passive house this requirement is strictly defined with the value being lower than $15 \mathrm{kWh} / \mathrm{m}^{2} \mathrm{a}$ in all countries. According to the Slovene legislative framework, the system of energy performance certification is defined in rules on the methodology of construction and issuance of building energy certificates (2010). On the basis of these rules, the classification of energy-efficient houses in classes A1, $\mathrm{A} 2$, B1, B2 and C, related to annual heating demand, is defined.

In an energy-efficient house the specified low energy demand can be achieved by well-considered design that includes a proper selection of building materials, excellent envelope insulation, good air tightness, thermally efficient glazing, a compact form of the building, construction without thermal bridges and passive solar design which is preconditioned by appropriate southern orientation with well-designed shading. On the other hand the optimal selection of active technical systems which include heat recovery ventilation, heating systems with ground source heat pumps, solar panels, lightning with low energy lamps and more, are required for achieving the best performance of an energy-efficient house and an appropriate quality of living. Lately, the option of embedding more glass surfaces into a building is becoming very popular due to energy efficiency. An appropriate size and orientation of such enlarged glazing areas in timber-frame structures is therefore very important from the viewpoint of the optimal energy-efficient design of buildings.

\section{Numerical Study}

In this chapter the parametric numerical case study of a two-storey house and its parametric analysis of an 
increased-proportion-of-the-glazing-surfaces impact on energy demand for heating and cooling is presented.

\subsection{Simulation model}

Description of the base case study model:

The external horizontal dimensions are $11.66 \mathrm{~m} \mathrm{x}$ $8.54 \mathrm{~m}$ for the ground floor and $11.66 \mathrm{~m} \mathrm{x} 9.79 \mathrm{~m}$ for the upper floor. The total heated floor area is $168 \mathrm{~m}^{2}$. The ground plan of the considered base-case study model is presented in detail in Žegarac Leskovar and Premrov (2011). A three-dimensional model of the house is shown in Fig.3.

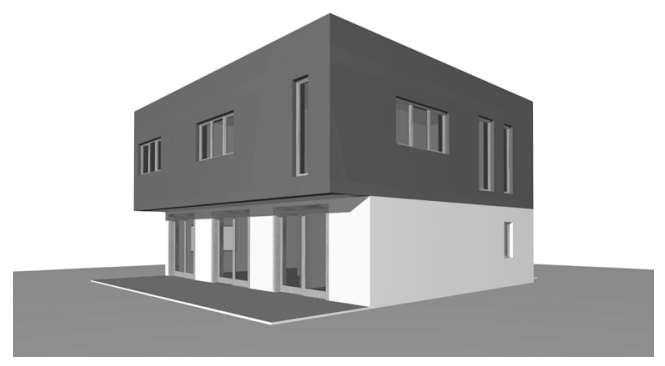

Fig.3. Three-Dimensional Model of the House

\section{Construction:}

The exterior walls are constructed using a timberframe macro-panel system. The exterior wall U-value of the base case is $0.137 \mathrm{~W} / \mathrm{m}^{2} \mathrm{~K}$. Owing to the characteristics of the exterior wall the base case model was labelled as TF 2 with the timber class $\mathrm{C} 22$ according to EN 338 (2003). The U-values of the other external construction elements are $0.135 \mathrm{~W} / \mathrm{m}^{2} \mathrm{~K}$ for the floor slab, $0.135 \mathrm{~W} / \mathrm{m}^{2} \mathrm{~K}$ for the flat roof and 0.130 $\mathrm{W} / \mathrm{m}^{2} \mathrm{~K}$ for the south-oriented overhang construction above the ground floor area.

Glazing:

A window glazing (Unitop 0.51 - 52 - UNIGLAS) with three layers of glass, two low-emissive coatings and krypton in the cavities for a normal configuration of 4E-12-4-12-E4, each cavity being $12 \mathrm{~mm}$ thick, with $4 \mathrm{~mm}$ thick glass panes, was installed. The glazing configuration with a g-value of $52 \%$ and $U_{g}$ $=0.51 \mathrm{~W} / \mathrm{m}^{2} \mathrm{~K}$ assures a high level of heat insulation and light transmission, Gustavsen et al. (2007). The window frame $\mathrm{U}$-value is $\mathrm{U}_{\mathrm{f}}=0.73 \mathrm{~W} / \mathrm{m}^{2} \mathrm{~K}$, while the frame width is $0.114 \mathrm{~m}$. The glazing-to-wall area ratio (AGAW) of the south-oriented façade is $27.6 \%$, while the AGAW values of the rest of the cardinal directions are $8.9 \%$ in the north, $10.5 \%$ in the east and $8.5 \%$ in the west façades.

\section{Climate and orientation:}

The house is located in Ljubljana and oriented with the longer side with the large glazed area facing south. The city of Ljubljana is located at an altitude of 298 $\mathrm{m}$, latitude of $46^{\circ} 03^{\prime}$ and longitude of $14^{\circ} 31^{\prime}$ east. Considered climate data from ARSO (2010) given by months are presented in Table 1.

Shading:

The house is constructed with a south-oriented extended overhang above the ground floor (see Fig.3.), which blocks the direct solar radiation from entering the ground floor windows to the south during the summer, while allowing it to enter in winter when the angle of incidence of the sun is lower. The rest of the windows on the upper floor and those of the east, west and north-oriented walls are shaded with external shading devices. The authors selected the temporary shading reduction factor $\mathrm{z}=50 \%$ for glazing areas in all four façades.

Internal gains and HVAC:

A value of $2.1 \mathrm{~W} / \mathrm{m}^{2}$ for internal heat gains from electric appliances and body heat was used in the PHPP (internal heat sources) calculation. The house is equipped with a central heat recovery unit. The efficiency of the selected unit which is placed within the thermal envelope is specified with values of $82 \%$ for heat recovery efficiency and $0.41 \mathrm{Wh} / \mathrm{m}^{3}$ for electrical efficiency. The average air change rate is set to a minimum recommended value of $0.30 \mathrm{~h}^{-1}$. To prevent overheating in the summer period the summer

Table 1. Climate Data for Ljubljana (ARSO, 2010)

\begin{tabular}{|c|c|c|c|c|c|c|c|c|c|c|c|c|c|}
\hline & JAN & FEB & MAR & APR & MAY & JUN & JUL & AUG & SEP & OCT & NOV & DEC & YEAR \\
\hline Average temperature & -1.1 & 1.4 & 5.4 & 9.9 & 14.6 & 17.8 & 19.9 & 19.1 & 15.5 & 0.4 & 4.6 & 0.0 & 9.8 \\
\hline mperature $<=0.0{ }^{\circ} \mathrm{C}$ & 23.7 & 18.2 & 11.5 & 2.1 & 0.1 & 0.0 & 0.0 & 0.0 & 0.0 & 2.0 & 10.5 & 21.3 & 89.6 \\
\hline $\begin{array}{l}\text { Nr. of } \\
\text { tempe }\end{array}$ & 0.0 & 0.0 & 0.0 & 0.6 & 4.7 & 12.2 & 19.6 & 169 & 6.3 & 0.3 & 0.0 & 0.0 & 60.6 \\
\hline Absolute highest temperature & 14.8 & 18.9 & 24.6 & 29.3 & 31.1 & 34.7 & 37.1 & 36.5 & 31.5 & 26.9 & 21.9 & 16.7 & 37.1 \\
\hline $\begin{array}{l}\text { Average relative humidity at } 7 \\
\operatorname{am}(\%)\end{array}$ & 91.1 & 89.5 & 89.5 & 86.9 & 85.9 & 86.2 & 87.0 & 91.8 & 95.1 & 94.4 & 92.6 & 91.3 & 90.2 \\
\hline $\begin{array}{l}\text { Average relative humidity at } 2 \\
\operatorname{pm}(\%)\end{array}$ & 78.1 & 66.9 & 57.9 & 52.9 & 51.9 & 54.5 & 51.6 & 53.9 & 59.0 & 64.3 & 75.2 & 81.2 & 62.4 \\
\hline $\begin{array}{l}\text { duration of solar } \\
\text { (h) }\end{array}$ & 47 & 85 & 128 & 162 & 210 & 221 & 260 & 230 & 164 & 116 & 56 & 37 & 1712 \\
\hline $\begin{array}{l}\text { Nr. of clear days } \\
\text { (cloudiness }<2 / 10 \text { ) }\end{array}$ & 1.8 & 2.8 & 3.4 & 3.1 & 2.8 & 2.9 & 5.1 & 4.5 & 1.7 & 2.0 & 1.3 & 1.0 & 32.5 \\
\hline $\begin{array}{l}\text { Nr. of cloudy days (cloudiness } \\
>8 / 10 \text { ) }\end{array}$ & 18.1 & 13.7 & 13.2 & 11.2 & 9.1 & 8.5 & 5.8 & 5.9 & 7.9 & 11.6 & 17.4 & 19.9 & 142.2 \\
\hline Nr. of days with fog & 15.3 & 10.2 & 6.8 & 4.2 & 4.9 & 5.1 & 6.1 & 9.8 & 15.2 & 15.4 & 12.8 & 15.2 & 120.8 \\
\hline
\end{tabular}


ventilation for cooling through manual window night ventilation with a corresponding air change rate of $0.20 \mathrm{~h}^{-1}$ was planned. Furthermore additional summer operation of the heat recovery ventilation system was planned as well. No other cooling devices were installed. The interior temperatures were designed to a $\mathrm{T}_{\min }$ of $20^{\circ} \mathrm{C}$ and $\mathrm{T}_{\max }$ of $25^{\circ} \mathrm{C}$. No solar collectors were installed.

Parameters varied:

The influence on the energy demand of the following factors was studied:

a.) The glazing size in four different cardinal directions; south, north, east and west.

b.) Modifications of the glazing area size were performed in the range of AGAW from $0 \%$ to nearly $80 \%$, and made step by step through adding window elements to the totally unglazed facade, as shown in Fig.4.

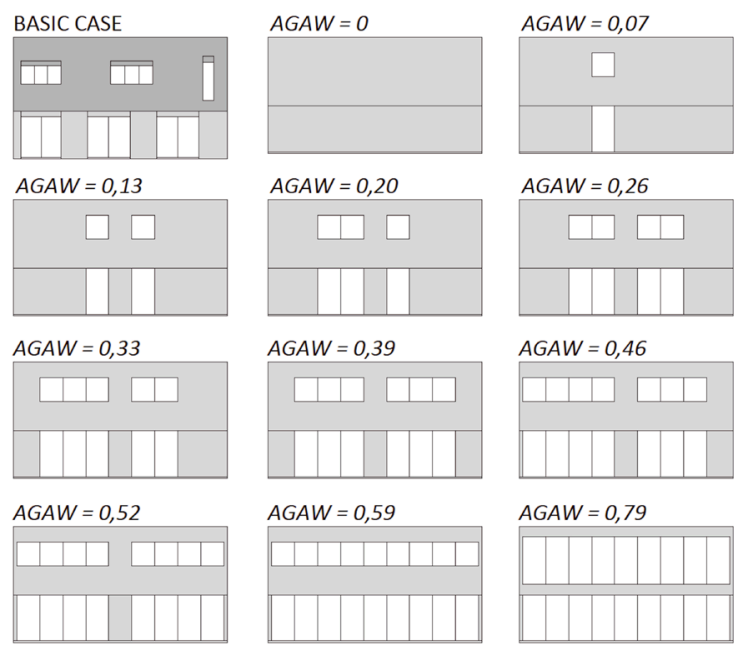

Fig.4. South-Oriented Façade of the Base-Case Model with Schemes of the Glazing Area Size Modification

c.) Modifications of the glazing area size were performed separately for each cardinal direction, for three timber-frame macro-panel systems: TF 1 with $\mathrm{U}=0.164 \mathrm{~W} / \mathrm{m}^{2} \mathrm{~K}$, TF 2 with $\mathrm{U}=0.137 \mathrm{~W} /$ $\mathrm{m}^{2} \mathrm{~K}$ and TF 3 with $\mathrm{U}=0.102 \mathrm{~W} / \mathrm{m}^{2} \mathrm{~K}$. Additional modifications of AGAW were made only for the south-oriented glazing areas for three classical single-panel systems with higher U-values: TFCL $1\left(\mathrm{U}=0.70 \mathrm{~W} / \mathrm{m}^{2} \mathrm{~K}\right)$, TFCL $2(\mathrm{U}=0.47$ $\left.\mathrm{W} / \mathrm{m}^{2} \mathrm{~K}\right)$ and TFCL $3\left(\mathrm{U}=0.30 \mathrm{~W} / \mathrm{m}^{2} \mathrm{~K}\right)$. The composition of the treated construction systems is shown in Fig.5.

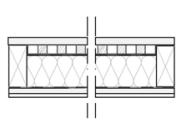

TF CL 2

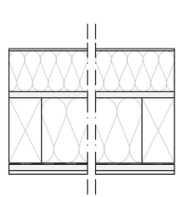

TF 1

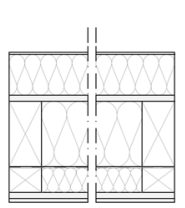

TF 2

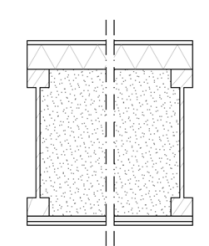

TF 3
Fig.5. Cross-Sections of the Analysed Exterior Wall Elements
Description of the software and calculation method:

The PHPP 2007 programme (Feist, 2007) was used to perform calculations of energy demand. The software was found to be able to describe the thermal building characteristics of passive houses surprisingly accurately, although it can be used also for low-energy house design. The calculation method of the parametric case study process is presented graphically in Fig. 6.
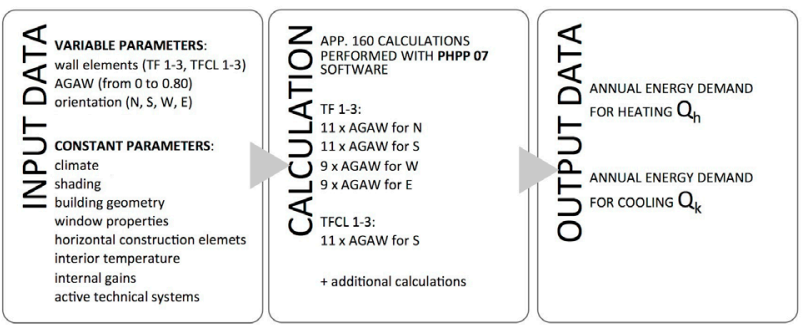

Fig.6. Case Study Calculation Method

\subsection{Results and discussion}

The comparison of annual energy demand for heating $\left(\mathrm{Q}_{\mathrm{h}}\right)$ and cooling $\left(\mathrm{Q}_{\mathrm{k}}\right)$ as a function of the glazing area size for different cardinal directions of the TF 2 construction system is presented in Fig.7.

a.)

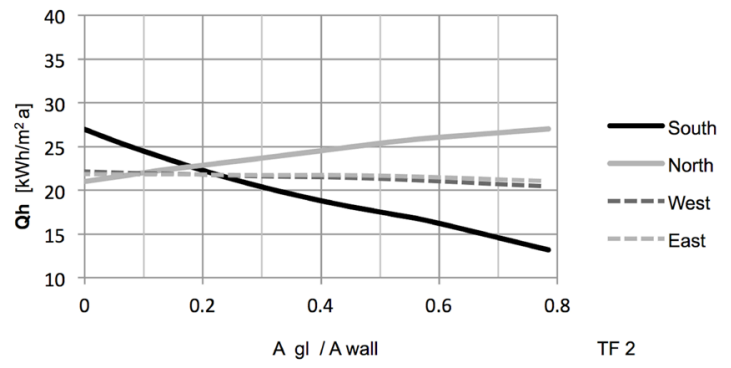

b.)

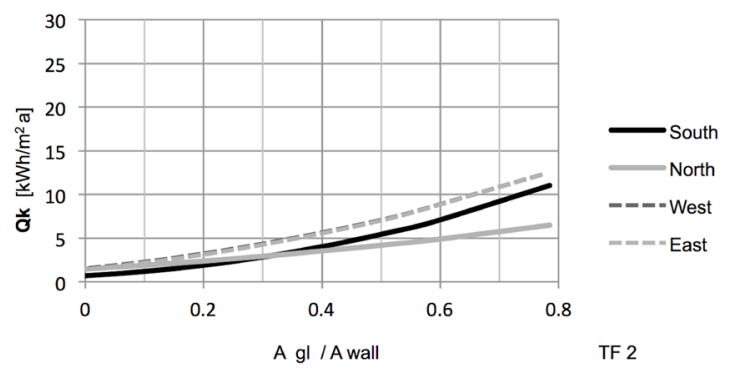

Fig.7. Energy Demand for a.) Heating $\left(Q_{h}\right)$ and b.) Cooling $\left(Q_{k}\right)$ in TF 2 System as a Function of AGAW

It is found that the largest influence of increasing the glazing area size is evident for the south orientation (Fig.7.a), where $\mathrm{Q}_{\mathrm{h}}$ decreases almost linearly with a growing AGAW and the heat gains at $\mathrm{AGAW}=0.79$ add up to almost $13 \mathrm{kWh} / \mathrm{m}^{2}$ a or for about $50 \%$ of the $\mathrm{Q}_{\mathrm{h}}$ value at $\mathrm{AGAW}=0$. The increase of $\mathrm{Q}_{\mathrm{h}}$ for almost $6 \mathrm{kWh} / \mathrm{m}^{2}$ a or $29 \%$ related to the energy demand for heating at the starting-point shows that the influence of changing the glazing area facing north is less expressive than that of its southern counterpart. East and west orientations show quite similar behaviour. To explain the positive influence of enlarged AGAW 
for the south façade it is necessary to present solar gains and transmission losses effected by using an appropriate size of glazing. Therefore, the results for the value of AGAW $=0.41$, which is the optimal glazing area size for the TF 2 system (see Table 2.), are graphically presented in Fig.8.

\begin{tabular}{|c|c|c|c|}
\hline \multirow{6}{*}{ 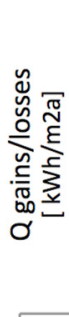 } & \multirow{2}{*}{$\begin{array}{r}40.0 \\
20.0 \\
0.0\end{array}$} & & 24.4 \\
\hline & & -17.4 & \\
\hline & \multirow{4}{*}{$\begin{array}{r}-20.0 \\
-40.0 \\
-60.0 \\
-80.0 \\
-100.0\end{array}$} & -26.2 & \\
\hline & & & \\
\hline & & & \\
\hline & & LOSSES & GAINS \\
\hline \multicolumn{2}{|c|}{ QS windows } & & 24.4 \\
\hline \multicolumn{2}{|c|}{ QT elements } & -26.2 & \\
\hline \multicolumn{2}{|c|}{$\square$ QT windows } & -17.4 & \\
\hline
\end{tabular}

Fig.8. Solar Gains and Transmission Losses by AGAW $=0.41$

It is evident that the solar gains are in this case higher $\left(\mathrm{QS}=24.4 \mathrm{kWh} / \mathrm{m}^{2} \mathrm{a}\right)$ than the transmission losses through the same windows $(\mathrm{QT}=-17.4 \mathrm{kWh} /$ $\mathrm{m}^{2} \mathrm{a}$ ) and therefore, the influence of the glazing in the south façade is positive.

A comparison of the cooling demand behaviour patterns presented in Fig.7.b shows the lowest $Q_{k}$ for the north orientation, while the west and east orientations show almost equivalent behaviour which is similar to the behaviour for the south orientation. From the presented data it is evident that an increase in the size of the glazing surfaces in all of the main cardinal directions has a relatively negative influence on the energy demand for cooling. The presented analyses generally accord well with the results of parametric study research on the effect of glazing type and size on annual heating and cooling demand for Swedish timber-frame offices, Bülow-Hübe (2001) and lowenergy houses, Persson (2006a) and Persson (2006b), taking into account of course differences in climate, as well as with some statements from design guidelines for comfortable low-energy homes considering the climate in Milan, Pagliano et al. (2007). Furthermore, the obtained results show a relatively good coincidence with the values for energy demand related to the different glazing area sizes with different glazing types for the case study in Amman, Hassouneh et al. (2010), taking into account some differences in external air temperature and duration of solar radiation considered in the calculations.

The behaviour of energy demand patterns of the TF 1 , TF 2 and TF 3 systems for the west and east directions are very similar, so that the patterns for the northern orientation show only the increase in energy demand. No noticeable decrease in energy demand, neither for $\mathrm{Q}_{\mathrm{h}}$ or $\mathrm{Q}_{\mathrm{k}}$, appears for these orientations $(\mathrm{N}, \mathrm{W}, \mathrm{E})$, therefore only the south direction, which is the main point of the authors' special interest, will be additionally analysed and compared for all construction systems. The most interesting point is the comparison of the $\mathrm{Q}_{\mathrm{h}}+\mathrm{Q}_{\mathrm{k}}$ demand for different construction systems (TF $1-$ TF 3), which is presented in Fig.9.

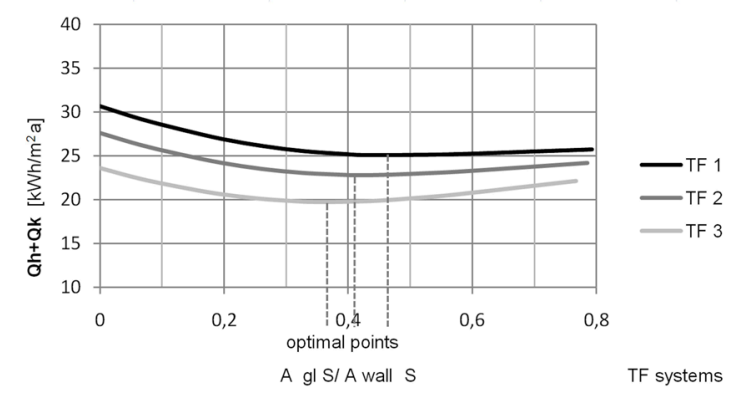

Fig.9. Comparison of Sum Total of Energy Demand for Heating and Cooling as a Function of AGAW for Southern Orientation of Selected TF Construction Systems (TF 1 - TF 3)

The results for sum total energy demand show an interesting appearance related to the optimal point with the lowest $\mathrm{Q}_{\mathrm{h}}+\mathrm{Q}_{\mathrm{k}}$ demand, which is clearly evident in the TF 3 construction system appearing at the range of AGAW $\approx 0.34-0.38$, quite evident in the TF 2 system at $\mathrm{AGAW} \approx 0.41$ and less evident in the TF 1 system at $\mathrm{AGAW} \approx 0.42-0.50$. The authors assume that the optimal share of glazing surface in south-oriented exterior walls depends on the thermal transmittance of the exterior wall. The optimal share of the glazing area in walls with extremely low U-values is smaller than that of walls with higher U-values. It is interesting to compare the results with a study performed by Inanici and Demirbilek (2000) who analysed variations of the window-to-wall ratio from 25 to $90 \%$ for different types of climate in Turkey. The results for the apartment units showed that when increasing the south facing window area the total energy load decreased for cool climates and increased for the warm climates. The optimum size in hot climates was $25 \%$ of the facade area $(\mathrm{AGAW}=0.25)$, which is lower as in the authors' case.

For purposes of comparison as well as for support in setting up the basic principle of the glazing surface's impact on energy behaviour patterns, an analysis of the classic single-panel prefabricated wall elements (Fig.1.) was carried out, but only for the south orientation. The TFCL 2 with $U_{\text {wall }}=0.47 \mathrm{~W} / \mathrm{m}^{2} \mathrm{~K}$, as well as the two additional fictive wall elements TFCL 1 with $\mathrm{U}_{\text {wall }}=0.70$ $\mathrm{W} / \mathrm{m}^{2} \mathrm{~K}$ and TFCL 3 with $\mathrm{U}_{\text {wall }}=0.30 \mathrm{~W} / \mathrm{m}^{2} \mathrm{~K}$ were analyzed. The analyses of the sum total of heating and cooling demand presented in Fig.10. seem to be the most interesting.

It is evident from the presented results that at higher $U$-values of exterior wall elements the functional optimum (lowest $\mathrm{Q}_{\mathrm{h}}+\mathrm{Q}_{\mathrm{k}}$ value) disappears, the $\mathrm{Q}_{\mathrm{h}}+\mathrm{Q}_{\mathrm{k}}$ function curve passes from parabolic dependence in construction systems with extremely low $U_{\text {wall }}$-values (TF 2 and TF 3) to linear dependence in construction 


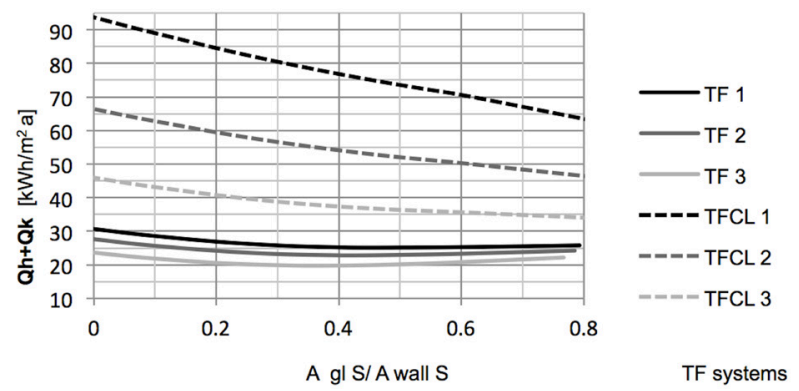

Fig.10. Comparison of Energy Demand for Heating and Cooling as a Function of AGAW for the Southern Orientation of Selected TF Construction Systems

systems with high $\mathrm{U}_{\text {wall-values }}$ (TFCL 1 - TFCL 3). The inclination of a function line presenting TFCL systems depends on the $\mathrm{U}_{\text {wall }}$-value.

\section{Generalisation of the Problem on One Single Independent Variable ( $\mathrm{U}_{\text {wall }}$-value)}

The main aim and scientific contribution of the presented study is in developing an innovative theoretical approach applicable for the architectural design of an optimal energy-efficient prefabricated timber house. In this way it is important to transform this complex energy related problem, dependent on the structural system, to only one single independent variable $\left(\mathrm{U}_{\text {wall }}\right.$-value $)$ which becomes the only variable parameter to determine the optimal glazing area size value $\left(\mathrm{AGAW}_{\mathrm{opt}}\right)$ for all contemporary prefabricated timber construction systems.

To set up the basic theory of the research on one single independent variable it is first necessary to observe and compare the energy demand behaviour for both, for the new macro-panel wall elements as well as for the classic wall elements with singlepanel construction, where the thermal transmittance of the selected wall elements is fictively set at an equal value. In Fig.10. the authors present a comparison of the energy demand $\mathrm{Q}_{\mathrm{h}}+\mathrm{Q}_{\mathrm{k}}$ for TF 3 and TFCL $2 \mathrm{a}$ construction systems, where wall elements with an equal $\mathrm{U}_{\text {wall }}$-value $=0.137 \mathrm{~W} / \mathrm{m}^{2} \mathrm{~K}$ are analysed. The $\mathrm{U}_{\text {wall }}$-value for TFCL 2 a system is obtained by adding a fictive mineral wool insulation with a thickness of 220 $\mathrm{mm}$ and $\lambda=0.04 \mathrm{~W} / \mathrm{mK}$ to the single-panel TFCL 2 wall element composition.

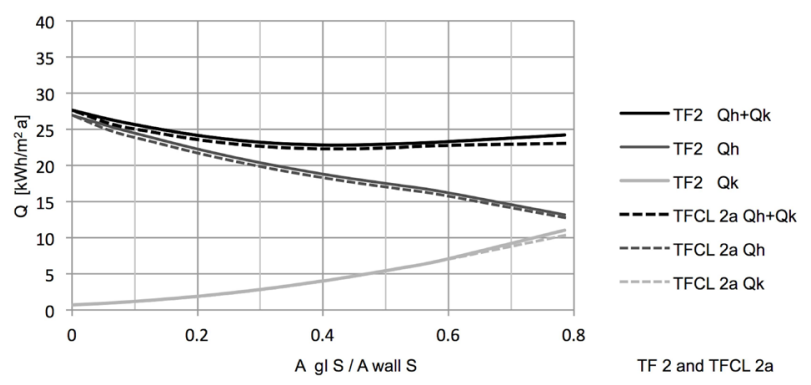

Fig.11. Comparison of Energy Demand as a Function of AGAW for Southern Orientation of Selected TF 3 and TFCL 2a Construction Systems with a Unique $\mathrm{U}_{\text {wall }}$-value $=0.102 \mathrm{~W} / \mathrm{m}^{2} \mathrm{~K}$
It is important for further approaches that in this case the results presented are almost equal for both construction systems. There are, however, some negligible differences evident at higher AGAW values, caused by a different thickness of wall elements which affects the fact that both systems have different total sizes of external wall area. Additionally, the authors also analysed three different massive panel systems (type KLH 1, KLH 2 and KLH 3) with different $\mathrm{U}_{\text {wall }}{ }^{-}$ values. The complete analysis with the calculated results for energy demand for heating and cooling is presented in Žegarac Leskovar and Premrov (2011). The calculated results for optimal AGAW values of all analysed types of external wall elements are presented in Table 2.

Table 2. Optimal Values of AGAW in a South Oriented External Wall Element for Selected Timber Construction Systems

\begin{tabular}{lccc}
\hline $\begin{array}{l}\text { Construct. } \\
\text { system }\end{array}$ & $\begin{array}{c}\mathrm{U}_{\text {wall }} \\
{\left[\mathrm{W} / \mathrm{m}^{2} \mathrm{~K}\right]}\end{array}$ & AGAW $_{\text {optim. }}$ & $\begin{array}{c}\mathrm{AGAW}_{\text {optim. }} \\
\text { adjusted }\end{array}$ \\
\hline TF 1 & 0.164 & $0.42-0.50$ & 0.47 \\
TF 2 & 0.137 & 0.41 & 0.41 \\
TF 3 & 0.102 & $0.34-0.38$ & 0.37 \\
KLH 1 & 0.181 & $0.52-0.54$ & 0.53 \\
KLH 2 & 0.148 & $0.41-0.46$ & 0.43 \\
KLH 3 & 0.124 & $0.38-0.40$ & 0.39 \\
systems & $\geq 0.193$ & $\approx 0.80$ & 0.80 \\
\hline
\end{tabular}

Based on the presented results in Table 2. it is now possible to analyse the relationship between the optimal glazing size in south-oriented external wall elements $\left(\mathrm{AGAW}_{\mathrm{opt}}\right)$ related to $\mathrm{Q}_{\mathrm{h}}+\mathrm{Q}_{\mathrm{k}}$ energy demand and the thermal transmittance of the wall element $\left(\mathrm{U}_{\text {wall }}\right)$. The data presented in Fig.12. show the values of AGAW, at which the sum total of heating and cooling demand reaches the lowest value, dependant on the U-value of the selected external wall element as the only independent variable. It is evident that the optimum or the convergence of the function curves for $\mathrm{AGAW}_{\text {opt }}$ appear only in systems with a $\mathrm{U}_{\text {wall }}$-value $\leq$ $0.193 \mathrm{~W} / \mathrm{m}^{2} \mathrm{~K}$.

As the $U_{\text {wall }}$-value is higher, the optimal share of south oriented glazing size is also higher. Reaching the limiting $\mathrm{U}_{\text {wall }}$-value $=0.193 \mathrm{~W} / \mathrm{m}^{2} \mathrm{~K}$, the values for an optimal AGAW converge towards the maximal glazing surface. For the analysed construction systems

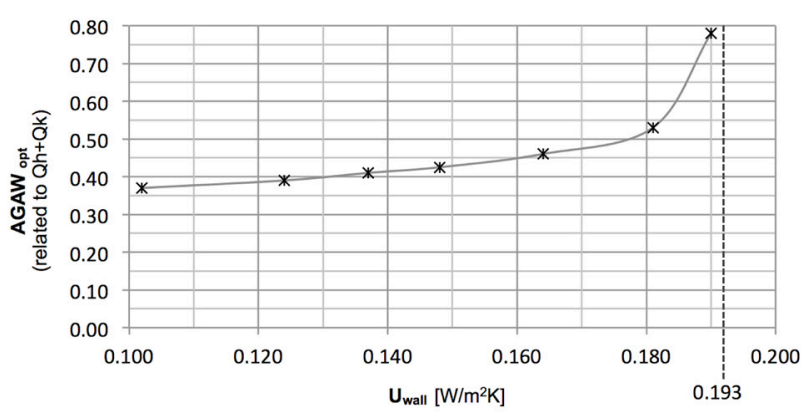

Fig.12. Optimal Values of AGAW in a South Oriented External Wall Element as a Function of $U_{\text {wall }}$-value for Timber Construction Systems 
with an $\mathrm{U}_{\text {wall }}$-value $>0.193 \mathrm{~W} / \mathrm{m}^{2} \mathrm{~K}$ no optimum or convergence for AGAW appears. The lowest $\mathrm{Q}_{\mathrm{h}}+\mathrm{Q}_{\mathrm{k}}$ is reached at the maximal AGAW value, although attention should be paid to the data concerning the overheating frequency.

\section{Conclusions}

It was found in the timber-frame house case that the influence of the glazing-to-wall area ratio on energy demand for heating is the largest and even very favourable when increasing the glazing surfaces in south-oriented exterior walls. Increasing the glazing surface in a north oriented external wall has a relatively negative influence on energy demand for heating. The influence of the west and east oriented glazing area is relatively insignificant.

It is evident from the results of the sum of the annual energy demand for heating and cooling $\left(\mathrm{Q}_{\mathrm{h}}+\mathrm{Q}_{\mathrm{k}}\right)$ that for the south orientation the optimum or at least the convergence of the function curve is present when installing glazing surfaces in contemporary macropanel timber-frame wall elements (Fig.9.). For the single-panel wall elements the increase of the south oriented glazing surfaces act positively in terms of the sum total of energy demand for heating and cooling, which is evident in the linear dependence of the $\mathrm{Q}_{\mathrm{h}}+\mathrm{Q}_{\mathrm{k}}$ function line according to the AGAW value (Fig.10.). This is especially important for the renovation principles of the existing timber-framed housing stock since the installation of large glazing areas in southoriented external walls improves the energy efficiency of the building.

However, due to the relatively high price of such special three-layer glazing type, this might not be the optimal solution from an economic point of view. In this way it is important to transform the energy problem on one single independent variable, the $\mathrm{U}_{\text {wall }}{ }^{-}$ value, to generalize the theoretical findings, based on an analysis of the authors' base case study, to be valid for the whole timber construction, regardless of the construction system. According to the results presented in Fig.12., the determined function for the optimal south oriented glazing size $\left(\mathrm{AGAW}_{\text {opt }}\right)$ offers us the opportunity to select the optimal way of renovation with a possible combination of improving the thermal properties of the external walls with the installation of an additional layer of insulation (decreasing U-wall value) and the installation of the optimal glazing size in the south-oriented façade, which is in the case of a lower $\mathrm{U}_{\text {wall }}$-value noticeably lower.

\section{References}

1) ARSO (2010) Climate conditions in Slovenia, http://meteo. arso.gov.si/uploads/probase/www/climate/text/sl/publications/ podnebne_razmere_v_sloveniji_71_00.pdf, (20.08.2010).

2) Bouden, $\bar{C}$. (2007) Influence of glass curtain walls on the building thermal energy consumption under Tunisian climatic conditions. Renewable Energy, 32, pp.141-156.

3) Bülow-Hübe, H. (2001) The Effect of Glazing Type and Size on Annual Heating and Cooling Demand for Swedish Offices, Report No TABK--01/1022: Department of Construction and Architecture, Lund University, Division of Energy and Building Design, Lund.

4) European Committee for Standardization (2003) EN 338:2003 E: Structural timber - Strength classes. Brussels.

5) Feist, V. (2007) Passive House Planning Package 2007 Guide book: Passivhaus Institut Dr. Volfgang Feist Darmstadt.

6) Gustavsen, A., Jelle, B. P., Arasteh, D. and Kohler, K. (2007) State-of-the-Art Highly Insulating Window Frames, Research and Market Review, Oslo.

7) Hassouneh, K., Alshboul, A. and Al-Salaymeh, A. (2010) Influence of windows on the energy balance of apartment buildings in Amman. Energy Conversion and Management, 51, pp.1583-1591.

8) Inanici, N. M. and Demirbilek, F. N. (2000) Thermal performance optimization of building aspect ratio and south window size in five cities having different climatic characteristic of Turkey. Building and Environment, 35 (1), pp.41-52.

9) Kozem Šilih, E. And Premrov, M. (2010) Analysis of timberframed wall elements with openings. Construction and Building Materials 24: 1656-1663.

10) Ministry of the Environment and spatial planning, Republic of Slovenia (2010) Rules on the methodology of construction and issuance of building energy certificates, Official Gazette of the Republic of Slovenia, 52/2010.

11) Pagliano, L. et al. (2007) The passive house standard in European warm climates, Design guidelines for comfortable low-energy homes - Part 2: Italy, Passive-On Project report.

12) Persson, ML, Roos A., Wall M. (2006a) Influence of window size on the energy balance of low energy houses. Energy and Buildings 38, pp.181-188.

13) Persson, ML., (2006b) Windows of Opportunities, The Glazed Area and its Impact on the Energy Balance of Buildings. PhD Thesis, Uppsala Universitet.

14) Premrov, M. and Kuhta, M., (2009) Influence of Fasteners Disposition on Behaviour of Timber-Framed Walls with Single Fibre-Plaster Sheathing Boards. Construction and Building Materials 23 (7), pp.2688-2693.

15) Steadman, P. and Brown F. (1987) Estimating the exposed surface area of the domestic stock, Energy and urban built form, 113-131, University of Cambridge.

16) Žegarac Leskovar, V. and Premrov, M. (2011) Impact of the proportion of glazing surface in south facade on energy efficiency of prefabricated timber buildings. Les Wood 63 (3), pp.56-65. 